\title{
Technical note: A pilot study using a mouse mastitis model to study differences between bovine associated coagulase-negative staphylococci
}

\author{
K. Breyne, ${ }^{* 1}$ S. De Vliegher, $†$ A. De Visscher, $†$ S. Piepers, $†$ and E. Meyer* \\ *Department of Pharmacology, Toxicology and Biochemistry, and \\ †M-team and Mastitis and Milk Quality Research Unit, Department of Reproduction, Obstetrics, and Herd Health, University of Ghent, \\ Salisburylaan 133, 9820 Merelbeke, Belgium
}

\section{ABSTRACT}

Coagulase-negative staphylococci (CNS) are a group of bacteria classified as either minor mastitis pathogens or commensal microbiota. Recent research suggests species- and even strain-related epidemiological and genetic differences within the large CNS group. The current pilot study investigated in 2 experiments whether a mouse mastitis model validated for bovine Staphylococcus aureus can be used to explore further differences between CNS species and strains. In a first dose titration experiment, a low inoculum dose of $S$. aureus Newbould 305 (positive control) was compared with increasing inoculum doses of a Staphylococcus chromogenes strain originating from a chronic bovine intramammary infection to a sham-inoculated mammary glands (negative control). In contrast to the high bacterial growth following inoculation with $S$. aureus, $S$. chromogenes was retrieved in very low levels at 24 $\mathrm{h}$ postinduction (p.i.). In a second experiment, the inflammation inflicted by 3 CNS strains was studied in mice. The host immune response induced by the $S$. chromogenes intramammary strain was compared with the one induced by a Staphylococcus fleurettii strain originating from cow bedding sawdust and by a $S$. chromogenes strain originating from a teat apex of a heifer. As expected, at 28 and 48 h p.i., low bacterial growth and local neutrophil influx in the mammary gland were induced by all CNS strains. As hypothesized, bacterial growth p.i. was the lowest for $S$. fleurettii compared with that induced by the $2 S$. chromogenes strains, and the overall immune response established by the $3 \mathrm{CNS}$ strains was less pronounced compared with the one induced by S. aureus. Proinflammatory cytokine profiling revealed that $S$. aureus locally induced IL-6 and IL$1 \beta$ but not TNF- $\alpha$, whereas, overall, CNS-inoculated glands lacked a strong cytokine host response but also induced IL-1 $\beta$ locally. Compared with both other CNS

Received August 2, 2014.

Accepted October 20, 2014

${ }^{1}$ Corresponding author: Koen.Breyne@UGent.be strains, S. chromogenes from the teat apex inflicted a more variable IL- $1 \beta$ response characterized by a more intense local reaction in several mice. This pilot study suggests that an intraductal mouse model can mimic bovine CNS mastitis and has potential as a complementary in vivo tool for future CNS mastitis research. Furthermore, it indicates that epidemiologically different bovine CNS species or strains induce a differential host innate immune response in the murine mammary gland.

Key words: coagulase-negative staphylococci strain, mouse mastitis model, bacterial growth, neutrophil influx, proinflammatory cytokine

\section{Technical Note}

Coagulase-negative staphylococci are a group of bacteria that cause mastitis in both heifers and multiparous cows (Thorberg et al., 2009; De Vliegher et al., 2012; Ajitkumar et al., 2013). Until recently, it was difficult to draw consistent conclusions on the relevance of CNS for bovine udder health. Some studies considered CNS as true mastitis pathogens, although most were retrieved from subclinical mastitis cases (Pyörälä and Taponen, 2009), whereas others considered CNS to be commensal bacteria with limited or absent negative effects on SCC, milk quality, and milk production (Schukken et al., 2009; De Vliegher et al., 2012). The development and validation of molecular identification techniques specifically for bovine-associated CNS were the basis to eliminate this confusion (Zadoks and Watts, 2009). Whereas older studies dealt with CNS as one homogenous and coherent group (Schukken et al., 2009; Piepers et al., 2010; Piepers et al., 2013), more recent studies addressed the CNS species separately, revealing heterogeneous characteristics between them (Avall-Jääskeläinen et al., 2013). In essence, 12 CNS species are frequently isolated from bovine milk. Evidence exists for diversity between and even within those species in their epidemiologic behavior and traits, such as persistence, antibiotic resistance, susceptibility to phagocytosis by mouse macrophages, and (putative) virulence (Piessens et al., 2011; Supré et al., 2011; 
Avall-Jääskeläinen et al., 2013; Vanderhaeghen et al., 2014).

To make further progress in our understanding of CNS mastitis, the interaction between CNS species and strains and the host should be studied in more detail. Ideally, such experimental infection studies are conducted using dairy cows. Unfortunately, these bovine studies are expensive and labor intensive. For those reasons, a mouse mastitis model was developed and characterized (Chandler, 1970) and has since been successfully validated for studying the specific host immune response to IMI with major mastitis pathogens, such as Escherichia coli and Staphylococcus aureus (Brouillette and Malouin, 2005; Demon et al., 2012; Demon et al., 2013), but not for CNS.

The usefulness of a mouse mastitis model as a complementary tool to investigate differences between bovine CNS species and strains was explored. Specifically, 2 experiments were performed to answer 3 clear-cut objectives: (1) whether bovine-associated CNS grow in the murine mammary gland, (2) whether they induce mastitis in mice, and (3) whether it is possible to detect differences in bacterial growth, clinical symptoms, and host immune response between CNS species or strains with a different origin using this mouse mastitis model.

The set-up of the 2 experiments is outlined in Figure 1. For both experiments, 8-wk-old female Hsd:ICR (CD1) mice that mated with 10-wk-old male Hsd:ICR (CD1) mice (Harlan Laboratories, Horst, the Netherlands) were used. Pups were weaned $\pm 10 \mathrm{~d}$ after parturition to ease the intraductal accessibility. All inoculations were performed $2 \mathrm{~h}$ postweaning under isoflurane anesthesia combined with a long-acting analgesic buprenorphine $(10 \mu \mathrm{g} / \mathrm{kg}$ of Vetergesic, Patheon UK Ltd., Swindon, UK) using a 32-gauge blunt needle. During both experiments, core body temperature of the mice was measured with a rectal thermistor. All experiments were approved by the committee on the ethics of animal experiments of Faculty of Veterinary Medicine, University of Ghent (permit number: EC2013/166).

In a first dose titration experiment, 4 increasing inoculum doses (i.e., $2.5 \times 10^{2}, 2.5 \times 10^{3}, 2.5 \times 10^{4}$, and 2.5 $\left.\times 10^{5} \mathrm{cfu} / 100 \mu \mathrm{L}\right)$ of a bovine-associated Staphylococcus chromogenes strain originating from a chronic IMI [IM (Supré et al., 2011)] were injected in the fourth gland pair of each of the 12 mice $\left(\mathrm{n}_{\text {mice/dose }}=3 ; \mathrm{n}_{\text {glands/ }}\right.$ dose $=6$ ) to evaluate both bacterial growth and immune cell influx in the mammary glands $24 \mathrm{~h}$ postinduction (p.i.). An additional 6 mice were inoculated with either a $100-\mu \mathrm{L}$ sham solution (PBS $+10 \%$ glycerol; $\mathrm{n}_{\text {mice }}=$ 3) or $1 \times 10^{2} \mathrm{cfu} / 100 \mu \mathrm{L}$ of Staphylococcus aureus Newbould $305\left(\mathrm{n}_{\text {mice }}=3\right)$ and were included as negative and positive controls, respectively (Figure 1A). Twenty-four hours p.i., all mice were first sedated by administer- ing a mixture of ketamine $(100 \mathrm{mg} / \mathrm{kg}$ of Anesketin, Eurovet Animal Health BV, Bladel, the Netherlands) with xylazine $(10 \mathrm{mg} / \mathrm{kg}$; Xylazini Hydrochloridum, Val d'Hony-Verdifarm, Beringen, Belgium) intraperitoneally and subsequently euthanized. After euthanasia, all S. chromogenes-inoculated glands ( $\mathrm{n}_{\text {glands/inoculum }}$ $=6$ ) were isolated to determine their bacterial load. Likewise, the S. chromogenes-inoculated glands with clinical signs of inflammation after dissection (i.e., red color, hard, swollen), as well as the 2 sham- and 2 S. aureus-inoculated glands, were further processed for histology. To quantify bacterial growth, the mammary glands were weighed, homogenized, and spotted $(20 \mu \mathrm{L})$ in serial logarithmic dilutions on Tryptic soy agar plates (Oxoid, Drongen, Belgium) overnight at $37^{\circ} \mathrm{C}$ to determine colony-forming units per $100 \mu \mathrm{L}$ and divided by the exact weight of a mammary gland (g). For the histologic sections, mammary glands were divided in 3 transverse proportions to validate the homogeneity of the infection: near the nipple (i.e., near the inoculation site), near the lymph node, and near the back. Two mammary glands for every inoculation (sham-, S. aureus-, and $10^{5}$ cfu of $S$. chromogenes IMinoculated glands) were fixed in buffered $3.5 \%$ formaldehyde (Sigma-Aldrich, St. Louis, MO) for $24 \mathrm{~h}$ at room temperature $\left(24^{\circ} \mathrm{C}\right)$. Subsequently, the samples were dehydrated and embedded in paraffin wax. Sections were deparaffinized, hydrated, and stained with hematoxylin and eosin (Sigma-Aldrich). As the inoculated mammary glands displayed clinical symptoms of inflammation following a $S$. chromogenes IM inoculum dose as high as $10^{5} \mathrm{cfu}$, but not at lower doses, only these CNS-inoculated glands were collected for histological evaluation.

In the second experiment, 2 additional bovine CNS strains were included [a Staphylococcus fleurettii strain originating from sawdust (Supré et al., 2011) and a $S$. chromogenes strain originating from a teat apex (TA) of a heifer (De Vliegher et al., 2004)]. The fourth gland pair of each of the 18 mice $\left(\mathrm{n}_{\text {mice }} / \mathrm{CNS}\right.$ strain $=6 ; \mathrm{n}_{\text {glands }}$ / CNS strain $=12$ ) were injected with either $S$. chromogenes IM, S. chromogenes TA, or $S$. fleurettii at an inoculum dose of approx. $10^{5} \mathrm{cfu}\left(9.6 \times 10^{4} \mathrm{cfu} / 100 \mu \mathrm{L}\right.$ of $S$. chromogenes IM, $9.3 \times 10^{4} \mathrm{cfu} / 100 \mu \mathrm{L}$ of $S$. chromogenes TA, and $8.5 \times 10^{4} \mathrm{cfu} / 100 \mu \mathrm{L}$ of $S$. fleurettii, respectively). Three additional mice were inoculated with $2.5 \times 10^{2} \mathrm{cfu} / 100 \mu \mathrm{L}$ of $S$. aureus Newbould 305 $\left(\mathrm{n}_{\text {mice/dose }}=3 ; \mathrm{n}_{\text {glands/dose }}=6\right)$ and included as a positive control (Figure 1B). The fifth gland pair of each mouse was inoculated with $100 \mu \mathrm{L}$ of sham solution and served as negative control. At 28 h p.i., 12 mice (3 mice per CNS strain and $3 S$. aureus Newbould 305 -inoculated mice) were sedated and euthanized as previously described. The other mice $(\mathrm{n}=9)$ were se- 


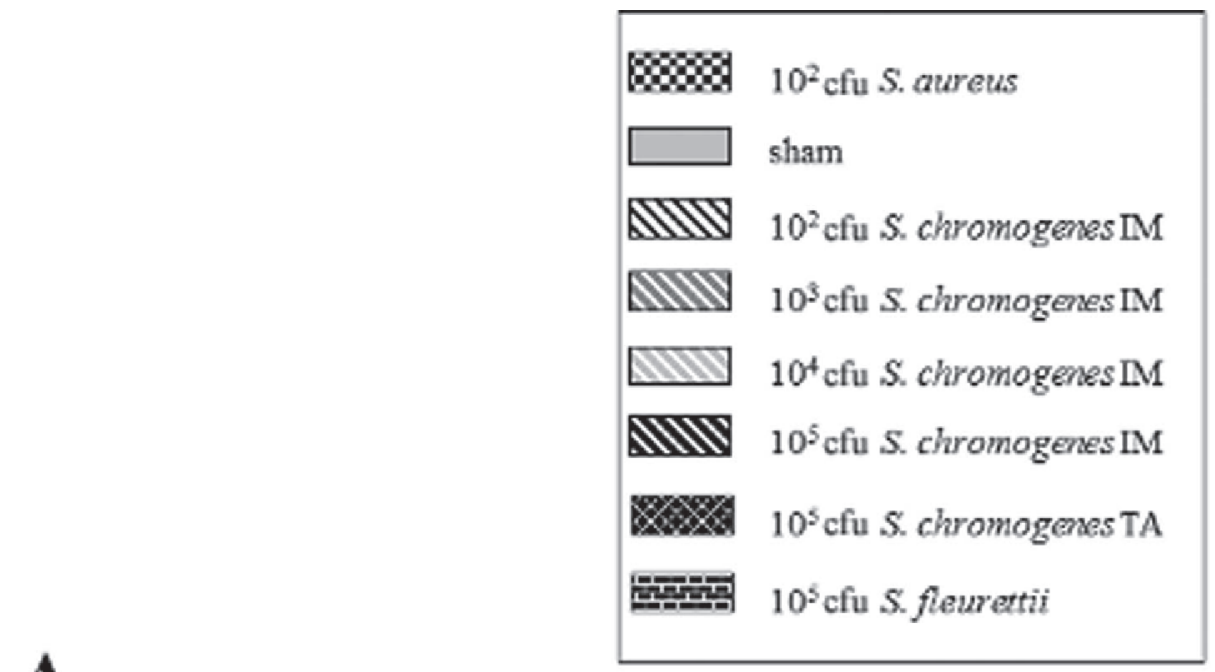

\section{Experiment 1: Inoculum dose-response Staphylococcus chromogenes IM ( 24 h p.i.)}

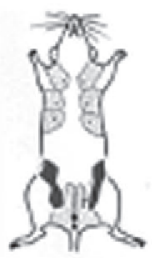

cfu Inoculum

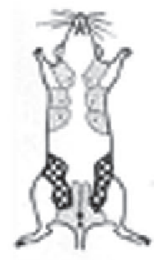

$10^{2}$
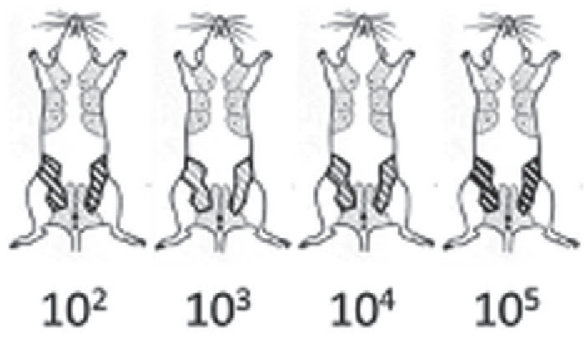

B

\section{Experiment 2: Comparison of different CNS strains (28 and $48 \mathrm{~h}$ p.i.)}

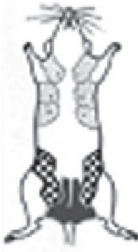

cfu

$10^{2}$

\section{S. aureus}

Inoculum

$\stackrel{+}{\text { sham }}$

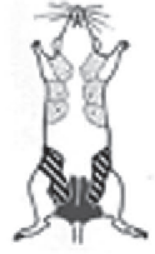

$10^{5}$

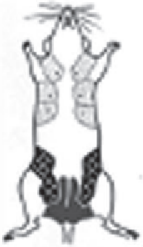

$10^{5}$

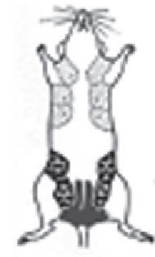

$10^{5}$

\section{S. chromogenes IM} $+$ sham
S. chromogenes TA

$+$

sham

\section{S. fleurettii}

$+$

sham

Figure 1. Schematic presentation of the set-up of the 2 experiments (A and B) performed in the current study. The patterned glands represent the glands inoculated with Staphylococcus aureus, Staphylococcus chromogenes intramammary (IM), S. chromogenes teat apex (TA), or Staphylococcus fleurettii, whereas the gray and dark gray mammary glands represent the unchallenged and the PBS/glycerol (sham)-inoculated mammary glands, respectively. p.i. = postinfection. 
dated and euthanized at $48 \mathrm{~h}$ p.i. After euthanasia, the inoculated glands were isolated to determine bacterial growth, cytokine levels, and histology. Bacterial growth was determined for every inoculum and time point as described. For cytokine quantification, mammary gland lysates were prepared from the mammary homogenates as previously reported (Breyne et al., 2014). Briefly, the IL- 6 , IL-1 $\beta$ levels, and TNF- $\alpha$ were determined in the protein suspensions $(50 \mu \mathrm{g})$ as described by the manufacturer with specific cytometric Bead Array kits (CBA, Becton Dickinson Biosciences, Erembodegem, Belgium) on a FACSArray instrument (Becton Dickinson Biosciences). For histology, a sagittal section was used. Two mammary glands for every inoculum and time point were fixed and prepared as described. Statistical differences in bacterial growth at 28 and 48 $\mathrm{h}$ p.i. and between the 3 CNS strains were determined using nonparametric or ANOVA tests (SPSS 20.0, IBM Corporation, Armonk, NY) with the $\log _{10}$-transformed colony-forming units per milliliter as outcome variables and the 3 CNS strains as the categorical independent variable. A similar approach was followed to determine the association between the inoculum ( $S$. aureus, $S$. chromogenes IM, S. chromogenes TA, or S. fleurettii) and the IL-6, IL-1 $\beta$, and TNF- $\alpha$ concentration either 28 or $48 \mathrm{~h}$ p.i. For parametric testing, mean values of inoculation groups were compared through Tukey post hoc testing. A $P$-value lower than 0.05 was considered statistically significant, values are represented as mean with SD.

Bacteria were extracted as described previously from randomly chosen CNS-inoculated mammary glands $\left(\mathrm{n}_{\text {glands } / \text { CNS strain }}=4\right)$ to validate the results of both experiments; commensal microbiota was determined in unchallenged lactating glands and sham-inoculated mammary glands $(\mathrm{n}=9$ and $\mathrm{n}=4)$. All colonies were counted on Tryptic soy agar plates and streaked onto Columbia agar (Oxoid) to obtain pure cultures. After $24 \mathrm{~h}$ of aerobic incubation at $37^{\circ} \mathrm{C}$, colonies were checked for purity and identified following National Mastitis Council procedures (Hogan et al., 1999). All CNS were identified to the species level using transfer RNA-intergenic spacer PCR (Supré et al., 2009). If no identification could be obtained, isolates were subjected to sequencing of the $16 \mathrm{~S}$ rRNA gene (Park et al., 2011).

\section{Experiment 1: IMI of Mice with Increasing Inoculum Doses of S. chromogenes IM}

Staphylococcus chromogenes IM-inoculated glands at $24 \mathrm{~h}$ p.i. displayed higher bacterial levels compared with sham-inoculated glands. Still, bacterial growth in the $S$. chromogenes IM inoculated glands was limited compared with the $S$. aureus Newbould 305-inoculated

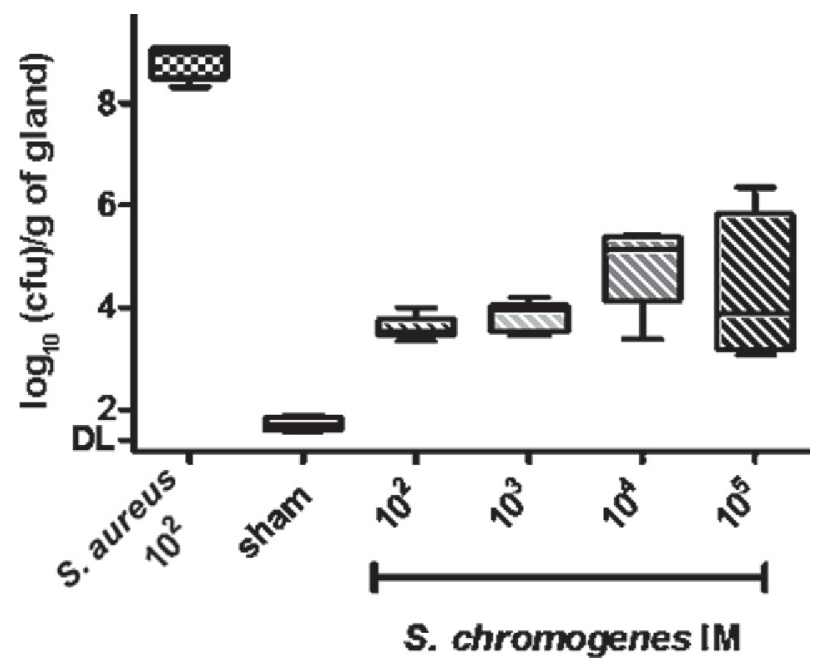

Figure 2. Bacterial growth (expressed as $\log _{10} \mathrm{cfu} / \mathrm{g}$ of gland) in mammary glands of mice inoculated at $24 \mathrm{~h}$ postinfection (p.i.) with PBS/glycerol (sham), Staphylococcus aureus, and Staphylococcus chromogenes intramammary (IM) in experiment 1 . The line in each box represents the median of these individual data sets. The color and pattern code of each group correspond to these explained in Figure 1. Error bars represent the standard deviation. DL = detection limit.

glands, regardless of the inoculum dose (Figure 2 and Table 1). The presence of $S$. chromogenes in the challenged glands was confirmed. A marked increase in mammary colony-forming units p.i. was observed in $S$. aureus Newbould 305-inoculated glands compared with both the sham- as well as $S$. chromogenes IM-inoculated glands (Figure 2).

Upon histological evaluation, both $S$. aureus and $S$. chromogenes IM induced an influx of immune cells in the alveoli (Figure 3B and C) that was absent in shaminoculated glands (Figure 3A). The latter had an intact alveolar structure with a swollen luminal area at 24 h p.i. with accumulated milk. In S. aureus-inoculated mammary glands, the general structural integrity of the alveoli was still present but the milk was replaced by a vast number of invading cells (Figure 3B; white arrow heads) that were tentatively identified as neutrophils mainly based on their characteristic polymorphonuclear feature. In analog, the alveoli from the $S$. chromogenes IM-inoculated glands were also packed with immune cells (Figure 3C; white arrow heads). This influx of cells in the mouse mammary gland was more invasive following $S$. aureus inoculation, as red blood cells were clearly observed in the interstitium, which was not the case after inoculation with S. chromogenes IM (Figure 3B; black arrow heads).

\section{Experiment 2: IMI of Mice with Different CNS Strains}

None of the 3 tested CNS strains had a significant overall change in the number of colony-forming units 
Table 1. Overview of the amount of bacteria $\left(\log _{10} \mathrm{cfu} / \mathrm{g}\right)$ in mammary glands at $24 \mathrm{~h}$ post infection (p.i.) of mice inoculated with Staphylococcus aureus, PBS/glycerol (sham), and Staphylococcus chromogenes IM of experiment 1

\begin{tabular}{lcccccc}
\hline & & \multicolumn{4}{c}{ S. chromogenes IM } \\
\cline { 4 - 7 } Item & S. aureus $\left(10^{2}\right)$ & Sham & $10^{2}$ & $10^{3}$ & $10^{4}$ & $10^{5}$ \\
\hline Minimum & 8.32 & 1.57 & 3.34 & 3.44 & 3.38 & 3.08 \\
25th Percentile & 8.49 & 1.60 & 3.47 & 3.51 & 4.14 & 3.18 \\
Median & 9.00 & 1.72 & 3.54 & 3.95 & 5.13 & 3.87 \\
75th Percentile & 9.06 & 1.86 & 3.76 & 4.04 & 5.38 & 5.84 \\
Maximum & 9.08 & 1.89 & 3.99 & 4.19 & 5.41 & 6.37 \\
\hline
\end{tabular}

between 28 and $48 \mathrm{~h}$ p.i. At both time points, no significant difference in bacterial growth was detected between $S$. chromogenes IM $\left(6.94 \pm 1.56 \log _{10} \mathrm{cfu} / \mathrm{g}\right.$ of gland) and $S$. chromogenes TA $\left(7.13 \pm 2.11 \log _{10} \mathrm{cfu} / \mathrm{g}\right.$ of gland; Figure 4). In contrast, S. fleurettii (4.41 \pm $1.01 \log _{10} \mathrm{cfu} / \mathrm{g}$ gland) was retrieved at significantly lower levels compared with both $S$. chromogenes strains $(P<0.01)$. Moreover, the first was not grown in the murine mammary gland but seems even decreased in $\log _{10}$ colony-forming units per gram of gland p.i. at 28 or $48 \mathrm{~h}$ compared with the administered inoculum. In analog with the first experiment, $S$. aureus displayed an exponential bacterial growth compared with each of the CNS p.i. The presence of each inoculated strain p.i. was confirmed. No distinct differences in histological features were observed between both time points p.i. All tested strains induced an influx of immune cells, of which the majority likely consisted of neutrophils. Still,
A
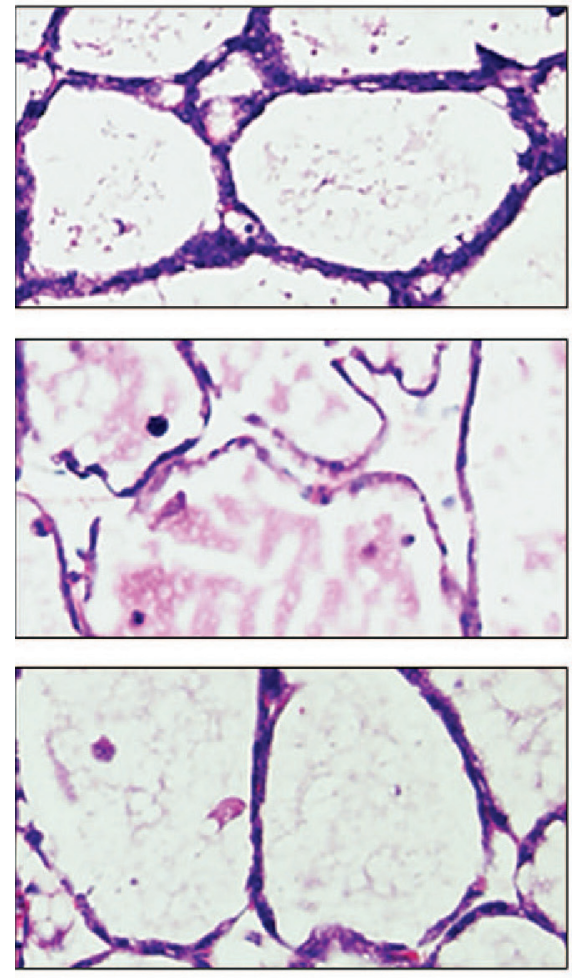

B
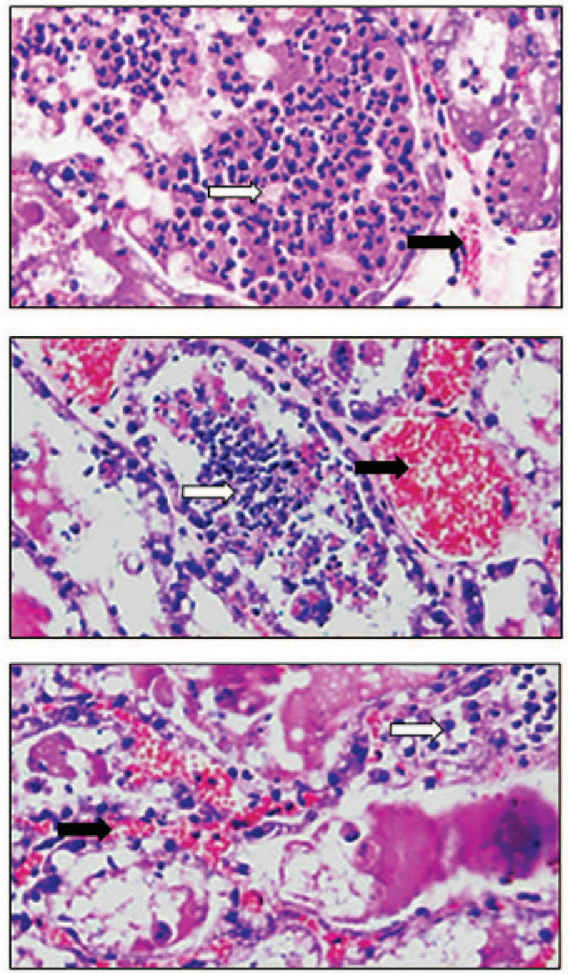

C
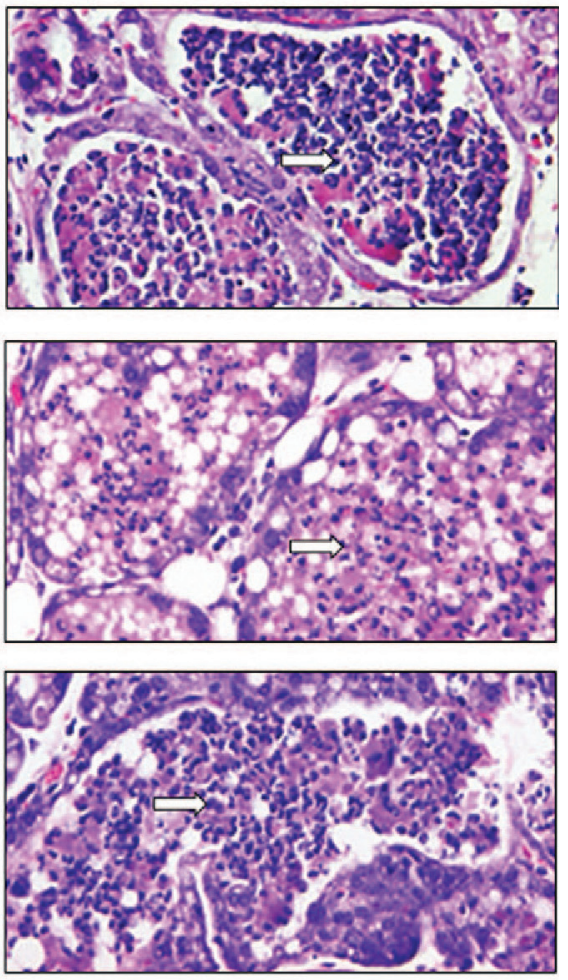

Figure 3. Representative hematoxylin and eosin-stained sections of mammary glands isolated from mice inoculated with (A) PBS/glycerol (sham), (B) Staphylococcus aureus, and (C) Staphylococcus chromogenes in experiment 1. The histology images in the upper panel are taken from sections sampled near the nipple, the ones in the middle panel near the subiliac lymph node, and the ones in the lowest panel near the dorsal gland tissue. The white arrows mark the immune cell content in the alveoli, whereas the black arrows point to the red blood cells in the interstitium. The scale bar represents a length of $200 \mu \mathrm{m}$. Color version available online. 
in marked contrast to $S$. aureus, no vascular congestion was observed in the interstitium after challenge with each of the CNS strains (Figure 5A, B, C, and D). Corroborating the results of the first experiment, shaminoculated control gland alveoli had an enlarged lumen filled with milk and lacked the presence of immune cells (Figure 5E). Both S. chromogenes strains had a similar scattered distribution of immune cells in contrast with the densely packed neutrophils retrieved in the alveolar lumen of the mouse mammary glands upon inoculation with S. fleurettii (Figure 5A, B, and C). Although a lower inoculum dose was injected, cytokine quantification revealed significantly higher IL-6 levels in the $S$. aureus-inoculated glands $\left(3.11 \pm 0.17 \log _{10}\right.$ IL-6 pg/mL) than in the sham- $\left(0.93 \pm 0.19 \log _{10}\right.$ IL- $\left.6 \mathrm{pg} / \mathrm{mL}\right)$ or CNS-inoculated glands $\left(1.15 \pm 0.56 \log _{10}\right.$ IL-6 pg/mL; $P<0.001$; Figure 6A). Furthermore, significant differences in the local IL-6 concentrations were not observed between the $3 \mathrm{CNS}$ strains, between the 2 time points p.i. within strains, or between the sham- and CNSinoculated glands. A similar trend was observed for the local IL-1 $\beta$ levels, which were substantially higher in $S$. aureus-inoculated glands $\left(2.97 \pm 0.14 \log _{10}\right.$ IL-1 $\beta \mathrm{pg} /$ $\mathrm{mL})$, compared with the sham- $\left(1.06 \pm 0.42 \log _{10}\right.$ IL-1 $\beta$ $\mathrm{pg} / \mathrm{mL}, P<0.001)$ and CNS-inoculated glands $(1.87$ $\pm 0.61 \log _{10}$ IL-1 $\beta \mathrm{pg} / \mathrm{mL} ; P<0.05$; Figure $\left.6 \mathrm{~B}\right)$. Still, the differences in local IL-1 $\beta$ concentrations induced by $S$. aureus compared with $S$. chromogenes IM, $S$. chromogenes TA, and S. fleurettii was less pronounced between $S$. aureus and $S$. chromogenes TA (i.e., $0.9 \pm$ $0.24 \log _{10}$ IL-1 $\left.\beta \mathrm{pg} / \mathrm{mL} ; \mathrm{n}=30 ; P<0.05\right)$ than between $S$. aureus and the 2 other CNS-strains (i.e., 1.07 $\pm 0.16 \log _{10}$ IL-1 $\beta \mathrm{pg} / \mathrm{mL}$ for $S$. chromogenes IM, $P<$ $0.001 ; 1.34 \pm 0.15 \log _{10}$ IL-1 $\beta \mathrm{pg} / \mathrm{mL}$ for $S$. fleurettii, $P$ $<0.001$; Figure 6B). No significant difference was observed in local IL-1 $\beta$ concentrations between the 2 time points p.i. Notably, a small difference was seen between the CNS- and sham-inoculated glands in their IL-1 $\beta$ concentration (i.e., $0.92 \pm 0.26 \log _{10}$ IL-1 $\beta \mathrm{pg} / \mathrm{mL} ; \mathrm{n}$ $=30 ; P<0.05)$ for both $S$. chromogenes strains but not for $S$. fleurettii and sham-inoculated glands. The TNF- $\alpha$ levels remained below the quantification limit for CNS-, S. aureus-, and sham-inoculated glands. Two out of 6 mice inoculated with $S$. chromogenes TA had a severe local irritation (1 mouse at $28 \mathrm{~h} \mathrm{p.i.} \mathrm{and} 1$ at $48 \mathrm{~h}$ p.i.). In these glands $(\mathrm{n}=4)$, a more pronounced bacterial growth as well as higher local IL-6 and IL$1 \beta$ concentrations were observed compared with other glands inoculated with the same strain, explaining the high variation for $S$. chromogenes TA in Figure $6 \mathrm{~A}$ and B. Such distinct differences in response among mammary glands inoculated with the same strain were not observed for $S$. chromogenes IM or S. fleurettii. Upon infection with each of the 3 CNS strains, the body temperature remained normothermic $\left(36.6 \pm 0.1^{\circ} \mathrm{C}\right.$; $\mathrm{n}=21)$. This was in marked contrast to $S$. aureusinoculated mice, which initially also remained normothermic until at least $24 \mathrm{~h}$ p.i., but became severely hypothermic (drop in body temperature of $7 \pm 1.6^{\circ} \mathrm{C}$; $P<0.001 ; \mathrm{n}=3$ ) within 48 h p.i.

For both experiments the residential microbiota in mammary glands of mice was verified in lactating and sham-inoculated glands. Twenty-three percent of the unchallenged mammary glands were sterile, whereas a limited number of bacterial species were extracted and genotypically identified from the remaining glands: Staphylococcus lentus (23\%), Kocuria spp. (7\%), Bacillus spp. (7\%), Alcaligenaceae spp. (15\%), Streptococcus spp. (15\%), and Microbacterium spp. (15\%; Table 2).

This pilot study explored the usefulness of a previously validated mouse mastitis model for bovine CNS research, which has been mentioned as relevant for human CNS research (Thomsen et al., 1985). A valid mouse model for CNS mastitis would circumvent the

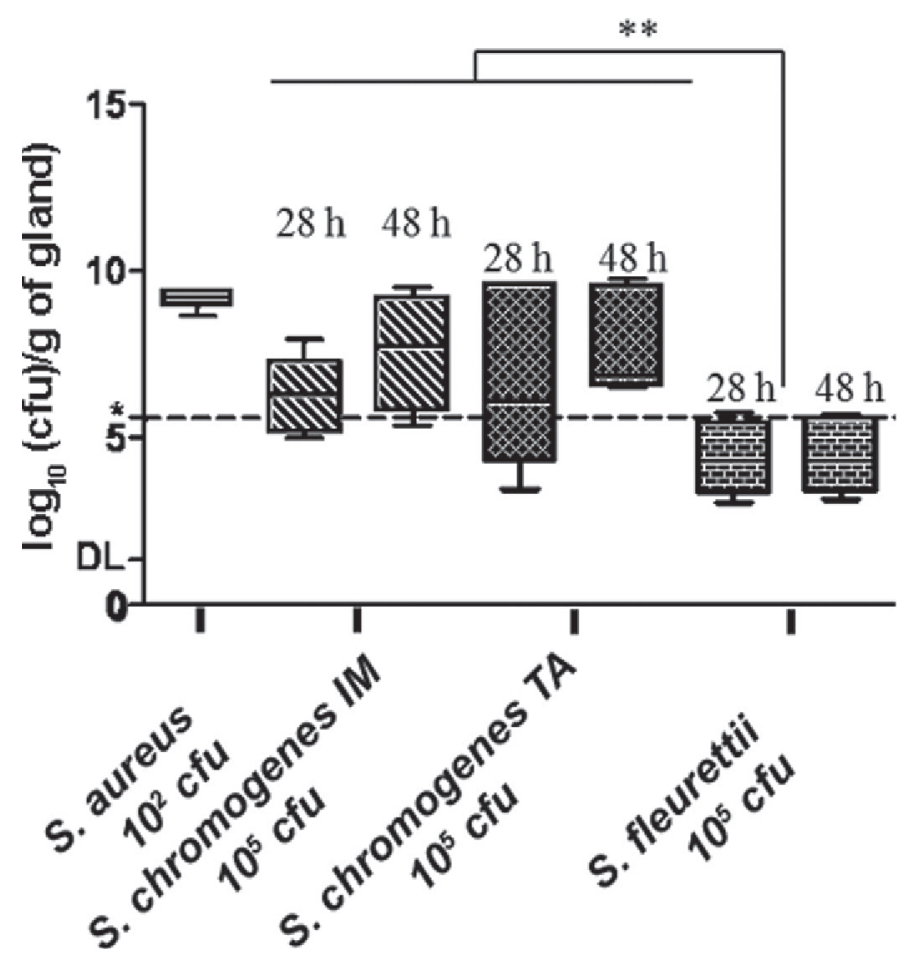

Figure 4. Bacterial growth (expressed as $\log _{10} \mathrm{cfu} / \mathrm{g}$ of gland) in mammary glands isolated from mice at $48 \mathrm{~h}$ postinoculation in experiment 2 and inoculated with Staphylococcus aureus, Staphylococcus chromogenes intramammary (IM), Staphylococcus chromogenes teat apex (TA), and Staphylococcus fleurettii after 28 (left box) or $48 \mathrm{~h}$ (right box). The line in each box represents the median of these individual data sets. $(* * P<0.01)$. The dotted line $(*)$ represents the $\log _{10}$ colony-forming units of CNS per gram of gland injected in the mammary gland of CNS-inoculated mice. The color and pattern code of each group correspond to the one clarified in Figure 1. Error bars represent the standard deviation. $\mathrm{DL}=$ detection limit. 

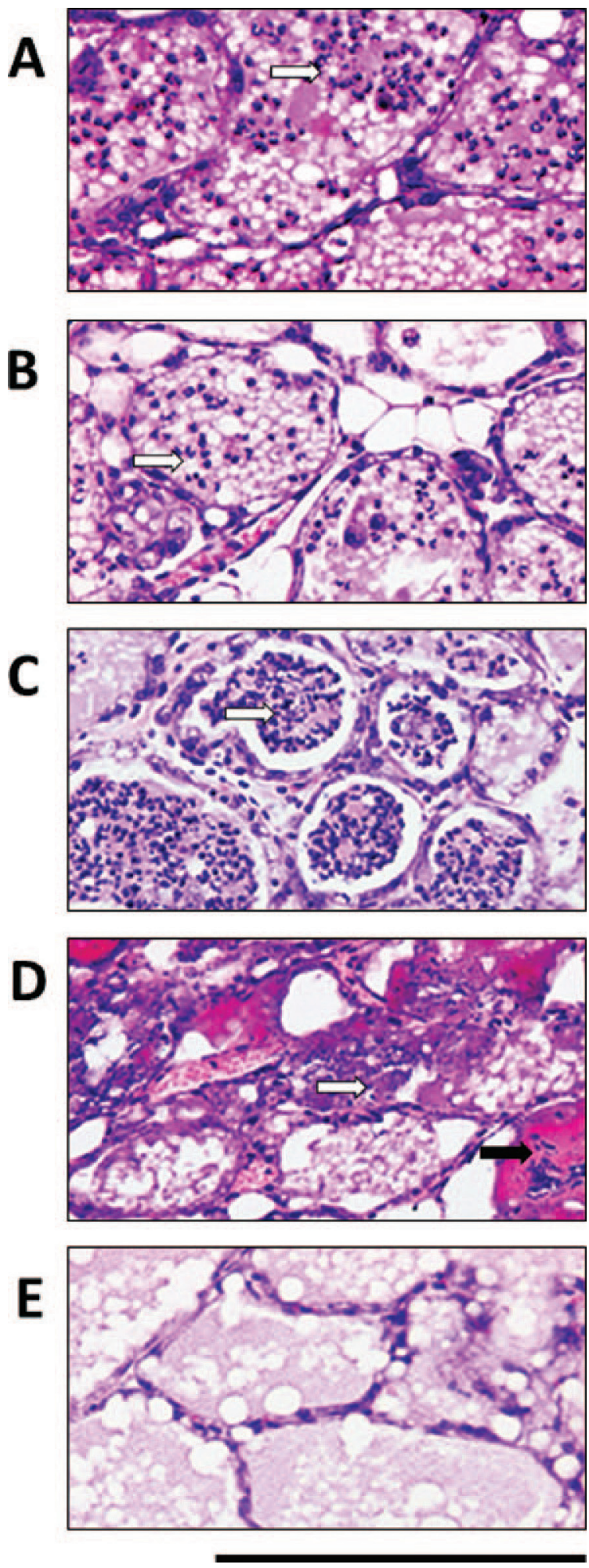

Figure 5. Representative hematoxylin and eosin-stained sections of (A) Staphylococcus chromogenes intramammary (IM), (B) Staphylococcus chromogenes teat apex (TA), (C) Staphylococcus fleurettii, (D) Staphylococcus aureus, and (E) PBS/glycerol (sham). The white arrows mark the immune cell content in the alveoli, whereas the black arrows point to the red blood cells in the interstitium. The scale bar represents a length of $200 \mu \mathrm{m}$. Color version available online. major drawbacks of cow challenge experiments. In the first experiment, our data unambiguously displayed limited growth in the murine mammary gland of the bovine CNS isolate that was administered. At $24 \mathrm{~h}$ p.i., the glands inoculated with the highest inoculum dose, $10^{5} \mathrm{cfu}$ of $\mathrm{CNS}$, were colored red and had a relatively mild alveolar influx of immune cells compared with the mammary glands that were inoculated with $S$. aureus. The latter results corroborate the observations in cows where high inocula of CNS are necessary to obtain colonization in the udder as described for $S$. chromogenes, S. simulans, and S. epidermis (Simojoki et al., 2009, 2011). Moreover, in contrast to mastitis caused by $S$. aureus, mastitis induced by CNS is less severe and accompanied by mild local signs, such as slight swelling of the udder and color changes in the milk (Taponen and Pyörälä, 2009). Remarkably, sham-inoculated glands were only occasionally sterile. Molecular identification of the bacteria isolated from these glands suggests they originate from the pups, as they are closely related to the commensal microbiota (Martin et al., 2004) from the murine gut and respiratory system (Rodrigue and Lavoie, 1996; Shim et al., 2009; Dimitriu et al., 2013). These bacteria were retrieved in limited number compared with the inoculum and are therefore not considered to have influenced our results to a large extent. Actually, the same species are also isolated from dairy products (i.e., raw milk or cheese; Quigley et al., 2011). To our knowledge, this is the first time that resident bacteria from murine mammary glands were considered in respect to experimentally induced mastitis in this laboratory animal.

In the second experiment, the mouse mastitis model allowed the comparison between 3 CNS isolates differentiated by their anticipated main reservoirs. Again, limited growth of CNS p.i. was observed compared with an $S$. aureus challenge, although each of the CNS strains as well as $S$. aureus caused a neutrophil influx following challenge. Additional cytokine data implied, in general, only a moderate proinflammatory immune response to a challenge with a CNS strain in comparison with S. aureus. This corroborated bovine studies, as IL-6 is retrieved following $S$. aureus IMI in contrast to CNS IMI (Hagiwara et al., 2001). Furthermore, the typical gram-negative pathogen-associated induction of TNF- $\alpha$ reported in cows (Bannerman, 2009) and in mice (Notebaert et al., 2008) was also lacking following gram-positive infections in mice. The higher virulence of $S$. aureus versus each of the CNS strains suggested through histology (experiment 1 and 2) and limited cytokine profiling (experiment 2) could be further endorsed with the overall clinical findings in the mice. It should be emphasized that the host innate immune response generated by $S$. aureus challenge was previ- 

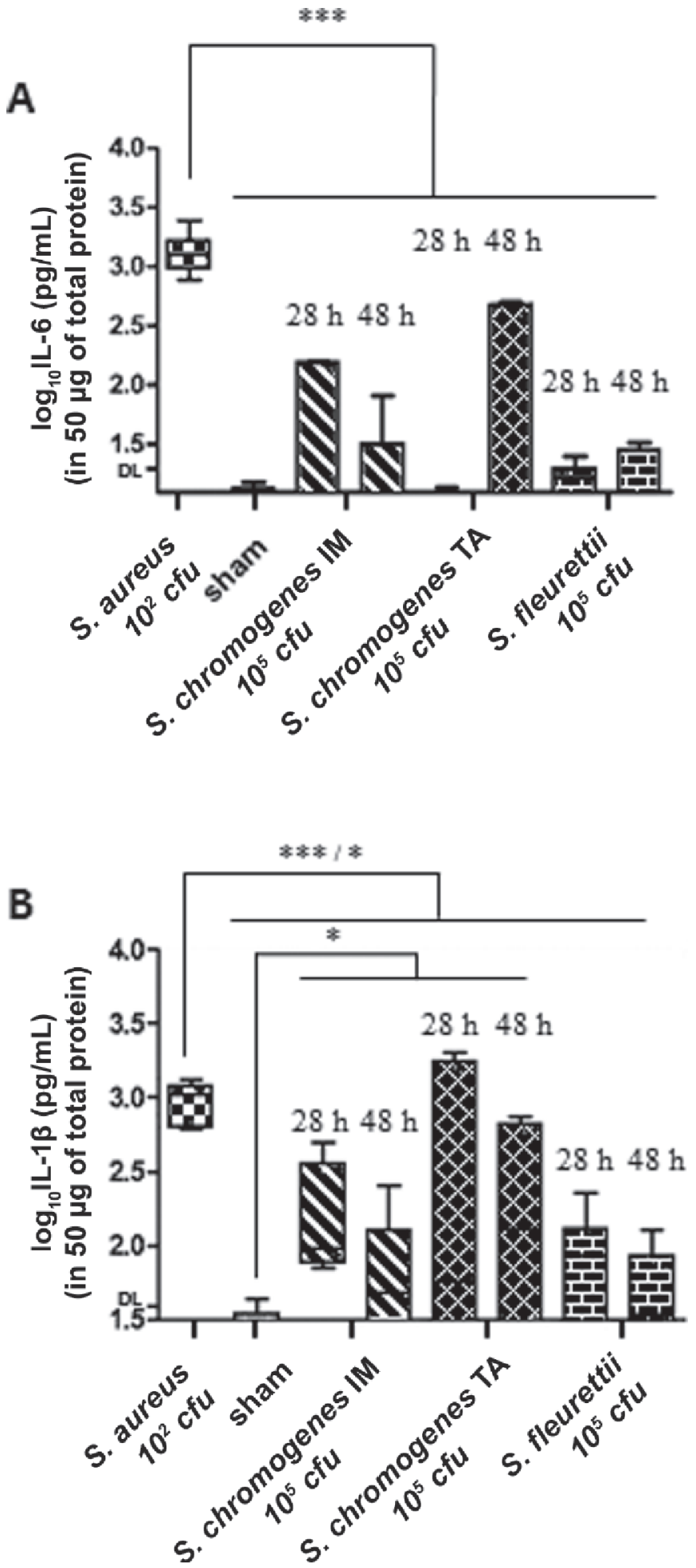

Figure 6. Interleukin-6 (A) and IL-1ß (B) cytokine levels in mammary glands isolated from mice of experiment 2 after 28 (left box) or $48 \mathrm{~h}$ (right box) inoculated with Staphylococcus aureus, PBS/glycerol (sham), and CNS. The line in each box represents the median of these values $\left({ }^{* * *} P<0.001 ;{ }^{*} P<0.05\right)$. Error bars represent the standard deviation. The color and pattern code of each group corresponds to the one clarified in Figure 1. IM = intramammary; TA = teat apex; $\mathrm{DL}=$ detection limit. ously reported by several groups (Bramley et al., 1989; Bhakdi and Tranum-Jensen, 1991; Dinges et al., 2000; Brouillette et al., 2004; Chinchali and Kaliwal, 2014) and therefore not unexpected. Our results substantiate the high sensitivity of mice toward the toxins produced by $S$. aureus in this in vivo mastitis model (Jonsson et al., 1985). The absence of coagulase production in transformed $S$. aureus remarkably diminished its intramammary virulence in mice (Jonsson et al., 1985); this most likely also relates to the minimal virulence of CNS in mice at first, as observed in the current study. The lower pathogenicity of the CNS strains compared with $S$. aureus explains the high prevalence of the former pathogens in the milk of clinically healthy cows and their less detrimental effects during bovine mastitis (Pate et al., 2012; Braem et al., 2013; Oikonomou et al., 2014).

Importantly, our data also reflect, at least to some extent, the difference observed in cows between the so-called environmental $S$. fleurettii and the so-called host-adapted S. chromogenes IM and S. chromogenes TA. Corroborating our bacterial growth, cytokine level data, the discriminating grouping of presumed neutrophils in the murine mammary gland sections, and the low prevalence in milk samples of cows allowed to speculate that $S$. fleurettii is able to colonize the milk habitat but is less likely to multiply locally compared with both $S$. chromogenes strains (Piessens et al., 2011; De Visscher et al., 2014). Although the number of animals should be increased to allow for a precise interpretation of the statistical relevance of our results, these suggest an underlying difference in the hosts' innate immune response between $S$. chromogenes IM and $S$. chromogenes TA. More specifically, the $S$. chromogenes IM strain might be more adapted to the intramammary niche (milk environment) and as such induce less pathophysiological effects compared with the likely more teat-adapted $S$. chromogenes TA.

In conclusion, our study suggests that, as previously demonstrated for $S$. aureus, the mouse model can be an attractive complementary in vivo tool for bovine CNS mastitis research while minding the limitations, such as the presence of a commensal murine mammary gland microbiota. Nevertheless, overall it mimics the mild inflammation in cows induced by an IMI with CNS through a neutrophil influx accompanied either with or without a low induction of certain proinflammatory cytokines. Moreover, the limited data of our pilot study tentatively suggest that the CNS mouse model can distinguish the differences in host response inflicted by different strains of the CNS group. Future research is warranted and should include infection studies with longer duration besides the comparison of even more bovine CNS isolates. This would allow drawing reliable conclu- 
Table 2. Residential microbiota in the mammary gland of mice

\begin{tabular}{|c|c|c|c|c|}
\hline $\begin{array}{l}\text { Treatment }^{1} \\
\text { and gland }\end{array}$ & Replicate & Dilution & $\begin{array}{l}\text { No. of } \\
\text { colonies }^{3}\end{array}$ & Result \\
\hline \multicolumn{5}{|l|}{ Lactating } \\
\hline 1 & $\mathrm{~A}$ & 1 & - & - \\
\hline 1 & B & 1 & 1 & Staphylococcus lentus \\
\hline 2 & A & 1 & 1 & Staphylococcus lentus \\
\hline 2 & B & 1 & 1 & Staphylococcus spp. \\
\hline 3 & A & 1 & 1 & Kocuria spp. \\
\hline 3 & $\mathrm{~B}$ & 1 & - & - \\
\hline 4 & $\mathrm{~A}$ & 1 & - & - \\
\hline 4 & $\mathrm{~B}$ & 1 & - & - \\
\hline 5 & $\mathrm{~A}$ & 1 & 2 & Microbacterium spp. \\
\hline 5 & B & 1 & 1 & Microbacterium spp. \\
\hline 6 & $\mathrm{~A}$ & 1 & 1 & Bacillaceae \\
\hline 6 & A & 1 & 1 & Staphylococcus lentus \\
\hline 6 & $\mathrm{~B}$ & 1 & 1 & Staphylococcus lentus \\
\hline 7 & $\mathrm{~A}$ & 1 & - & - \\
\hline 7 & B & 1 & - & - \\
\hline 8 & $\mathrm{~A}$ & 1 & - & - \\
\hline 8 & B & 1 & - & - \\
\hline 9 & $\mathrm{~A}$ & 1 & - & - \\
\hline 9 & B & 1 & 2 & Microbacterium spp. \\
\hline \multicolumn{5}{|l|}{ Sham } \\
\hline 1 & $\mathrm{~A}$ & 1 & - & - \\
\hline 1 & B & 1 & 1 & Streptococcus spp. \\
\hline 1 & $\mathrm{~A}$ & 2 & 55 & Streptococcus spp. \\
\hline 1 & B & 2 & 73 & Streptococcus acidominimus \\
\hline 2 & $\mathrm{~A}$ & 1 & 6 & Streptococcus acidominimus \\
\hline 2 & B & 1 & 5 & Streptococcus spp. \\
\hline 2 & $\mathrm{~A}$ & 2 & 31 & Streptococcus acidominimus \\
\hline 2 & B & 2 & 49 & Streptococcus acidominimus \\
\hline 3 & $\mathrm{~A}$ & 1 & 31 & Alcaligenaceae \\
\hline 3 & B & 1 & 38 & Alcaligenaceae \\
\hline 3 & A & 2 & 5 & Alcaligenaceae \\
\hline 3 & $\mathrm{~B}$ & 2 & 6 & Alcaligenaceae \\
\hline 3 & A & 1 & 22 & Alcaligenaceae \\
\hline 4 & $\mathrm{~B}$ & 1 & 20 & Alcaligenaceae \\
\hline 4 & $\mathrm{~A}$ & 2 & 2 & Alcaligenaceae \\
\hline 4 & $\mathrm{~B}$ & 2 & 2 & Alcaligenaceae \\
\hline
\end{tabular}

${ }^{1}$ Lactating mammary glands were not injected and not weaned from the litter; sham-inoculated glands were weaned from the litter for at least $24 \mathrm{~h}$ before inoculating with PBS.

${ }^{2}$ Different numbers represents different glands.

${ }^{3}$ The number of colonies with a distinct phenotype compared with other colonies.

sions on the specific differences between CNS species and strains, as observed in cows. Moreover, analyzing the influence of the mouse strain would be valuable for the in-depth validation of our mouse mastitis CNS model. Finally, this mouse model is potentially also an elegant tool to explore the inflammatory factors including cytokines that are enhanced by CNS when inducing a local neutrophil influx.

\section{ACKNOWLEDGMENTS}

The authors thank Bart de Pauw, Jurgen De Craene, and Lobke de Bels from the Department of Morphology, Kristel Demeyere from the Department of Pharmacology, Toxicology and Biochemistry, Lars Hulpio from the M-team and Mastitis and Milk Quality Research Unit, Department of Reproduction, Obstetrics, and
Herd Health and Bram Kaptein, all from University of Ghent, for their excellent help and technical assistance.

\section{REFERENCES}

Ajitkumar, P., H. W. Barkema, R. N. Zadoks, D. W. Morck, F. J. U. M. van der Meer, and J. De Buck. 2013. High-resolution melt analysis for species identification of coagulase-negative staphylococci derived from bovine milk. Diagn. Microbiol. Infect. Dis. $75: 227-234$.

Avall-Jääskeläinen, S., J. Koort, H. Simojoki, and S. Taponen. 2013. Bovine-associated CNS species resist phagocytosis differently. BMC Vet. Res. 9:227.

Bannerman, D. D. 2009. Pathogen-dependent induction of cytokines and other soluble inflammatory mediators during intramammary infection of dairy cows. J. Anim. Sci. 87:10-25.

Bhakdi, S., and J. Tranum-Jensen. 1991. Alpha-toxin of Staphylococcus aureus. Microbiol. Rev. 55:733-751.

Braem, G., S. De Vliegher, B. Verbist, V. Piessens, E. Van Coillie, L. De Vuyst, and F. Leroy. 2013. Unraveling the microbiota of teat apices of clinically healthy lactating dairy cows, with spe- 
cial emphasis on coagulase-negative staphylococci. J. Dairy Sci. 96:1499-1510.

Bramley, A. J., A. H. Patel, M. O'Reilly, R. Foster, and T. J. Foster. 1989. Roles of alpha-toxin and beta-toxin in virulence of Staphylococcus aureus for the mouse mammary gland. Infect. Immun. $57: 2489-2494$.

Breyne, K., S. K. Cool, D. Demon, K. Demeyere, T. Vandenberghe, P. Vandenabeele, H. Carlsen, W. Van Den Broeck, N. N. Sanders, and E. Meyer. 2014. Non-classical proIL-1beta activation during mammary gland infection is pathogen-dependent but caspase- 1 independent. PLoS ONE. In press.

Brouillette, E., G. Grondin, U. Lefebvre, B. G. Talbot, and F. Malouin. 2004. Mouse mastitis model of infection for antimicrobial compound efficacy studies against intracellular and extracellular forms of Staphylococcus aureus. Vet. Microbiol. 101:253-262.

Brouillette, E., and F. Malouin. 2005. The pathogenesis and control of Staphylococcus aureus-induced mastitis: Study models in the mouse. Microbes Infect. 7:560-568.

Chandler, R. L. 1970. Experimental bacterial mastitis in the mouse. J. Med. Microbiol. 3:273-282.

Chinchali, J. F., and B. B. Kaliwal. 2014. Histopathology of mammary gland in Staphylococcus aureus-induced mastitis in mice. Asian Pac. J. Trop. Dis. 4:S320-S325.

De Visscher, A., K. Supré, F. Haesebrouck, R. N. Zadoks, V. Piessens, E. Van Coillie, S. Piepers, and S. De Vliegher. 2014. Further evidence for the existence of environmental and host-associated species of coagulase-negative staphylococci in dairy cattle. Vet. Microbiol. 172:466-474.

De Vliegher, S., L. K. Fox, S. Piepers, S. McDougall, and H. W. Barkema. 2012. Invited review: Mastitis in dairy heifers: Nature of the disease, potential impact, prevention, and control. J. Dairy Sci. 95:1025-1040.

De Vliegher, S., G. Opsomer, A. Vanrolleghem, L. A. Devriese, O. C. Sampimon, J. Sol, H. W. Barkema, F. Haesebrouck, and A. de Kruif. 2004. In vitro growth inhibition of major mastitis pathogens by Staphylococcus chromogenes originating from teat apices of dairy heifers. Vet. Microbiol. 101:215-221.

Demon, D., K. Breyne, G. Schiffer, and E. Meyer. 2013. Short communication: Antimicrobial efficacy of intramammary treatment with a novel biphenomycin compound against Staphylococcus aureus, Streptococcus uberis, and Escherichia coli-induced mouse mastitis. J. Dairy Sci. 96:7082-7087.

Demon, D., C. Ludwig, K. Breyne, D. Guede, J. C. Dorner, R. Froyman, and E. Meyer. 2012. The intramammary efficacy of first generation cephalosporins against Staphylococcus aureus mastitis in mice. Vet. Microbiol. 160:141-150.

Dimitriu, P. A., G. Boyce, A. Samarakoon, M. Hartmann, P. Johnson, and W. W. Mohn. 2013. Temporal stability of the mouse gut microbiota in relation to innate and adaptive immunity. Environ. Microbiol. Rep. 5:200-210.

Dinges, M. M., P. M. Orwin, and P. M. Schlievert. 2000. Exotoxins of Staphylococcus aureus. Clin. Microbiol. Rev. 13:16-34.

Hagiwara, K., H. Yamanaka, K. Hisaeda, S. Taharaguchi, R. Kirisawa, and H. Iwai. 2001. Concentrations of IL-6 in serum and whey from healthy and mastitic cows. Vet. Res. Commun. 25:99-108.

Hogan, J., R. Gonzalez, R. Harmon, S. Nickerson, S. Oliver, J. Pankey, and K. Smith. 1999. Laboratory Handbook on Bovine Mastitis. The National Mastitis Council Inc., Madison, WI.

Jonsson, P., M. Lindberg, I. Haraldsson, and T. Wadstrom. 1985. Virulence of Staphylococcus aureus in a mouse mastitis model: Studies of alpha hemolysin, coagulase, and protein A as possible virulence determinants with protoplast fusion and gene cloning. Infect. Immun. 49:765-769

Martin, R., S. Langa, C. Reviriego, E. Jimenez, M. L. Marin, M. Olivares, J. Boza, J. Jimenez, L. Fernandez, J. Xaus, and J. M. Rodriguez. 2004. The commensal microflora of human milk: new perspectives for food bacteriotherapy and probiotics. Trends Food Sci. Technol. 15:121-127.

Notebaert, S., H. Carlsen, D. Janssen, P. Vandenabeele, R. Blomhoff, and E. Meyer. 2008. In vivo imaging of NF-kappaB activity during
Escherichia coli-induced mammary gland infection. Cell. Microbiol. 10:1249-1258.

Oikonomou, G., M. L. Bicalho, E. Meira, R. E. Rossi, C. Foditsch, V. S. Machado, A. G. Teixeira, C. Santisteban, Y. H. Schukken, and R. C. Bicalho. 2014. Microbiota of cow's milk: Distinguishing healthy, sub-clinically and clinically diseased quarters. PLoS ONE 9:e85904.

Park, J. Y., L. K. Fox, K. S. Seo, M. A. McGuire, Y. H. Park, F. R. Rurangirwa, W. M. Sischo, and G. A. Bohach. 2011. Detection of classical and newly described staphylococcal superantigen genes in coagulase-negative staphylococci isolated from bovine intramammary infections. Vet. Microbiol. 147:149-154.

Pate, M., I. Zdovc, J. Avberšek, M. Ocepek, A. Pengov, and O. Podpečan. 2012. Coagulase-negative staphylococci from non-mastitic bovine mammary gland: characterization of Staphylococcus chromogenes and Staphylococcus haemolyticus by antibiotic susceptibility testing and pulsed-field gel electrophoresis. J. Dairy Res. 79:129-134.

Piepers, S., G. Opsomer, H. W. Barkema, A. de Kruif, and S. De Vliegher. 2010. Heifers infected with coagulase-negative staphylococci in early lactation have fewer cases of clinical mastitis and higher milk production in their first lactation than noninfected heifers. J. Dairy Sci. 93:2014-2024.

Piepers, S., Y. H. Schukken, P. Passchyn, and S. De Vliegher. 2013. The effect of intramammary infection with coagulase-negative staphylococci in early lactating heifers on milk yield throughout first lactation revisited. J. Dairy Sci. 96:5095-5105.

Piessens, V., E. Van Coillie, B. Verbist, K. Supre, G. Braem, A. Van Nuffel, L. De Vuyst, M. Heyndrickx, and S. De Vliegher. 2011. Distribution of coagulase-negative Staphylococcus species from milk and environment of dairy cows differs between herds. J. Dairy Sci. 94:2933-2944.

Pyörälä, S., and S. Taponen. 2009. Coagulase-negative staphylococciemerging mastitis pathogens. Vet. Microbiol. 134:3-8.

Quigley, L., O. O'Sullivan, T. P. Beresford, R. P. Ross, G. F. Fitzgerald, and P. D. Cotter. 2011. Molecular approaches to analysing the microbial composition of raw milk and raw milk cheese. Int. J. Food Microbiol. 150:81-94.

Rodrigue, L., and M. C. Lavoie. 1996. Comparison of the proportions of oral bacterial species in BALB/c mice from different suppliers. Lab. Anim. 30:108-113.

Schukken, Y. H., R. N. Gonzalez, L. L. Tikofsky, H. F. Schulte, C. G. Santisteban, F. L. Welcome, G. J. Bennett, M. J. Zurakowski, and R. N. Zadoks. 2009. CNS mastitis: Nothing to worry about? Vet. Microbiol. 134:9-14.

Shim, S. B., J. K. Seo, M. K. Jang, S. W. Jee, S. H. Lee, C. J. Bae, J.-H. Kang, J.-M. Woo, J. H. Kang, and B. G. Kim. 2009. Distribution and seasonal fluctuation of bacteria isolated from mice and rats. Lab. Anim. Res. 25:295-301.

Simojoki, H., T. Orro, S. Taponen, and S. Pyörälä. 2009. Host response in bovine mastitis experimentally induced with Staphylococcus chromogenes. Vet. Microbiol. 134:95-99.

Simojoki, H., T. Salomaki, S. Taponen, A. Iivanainen, and S. Pyörälä. 2011. Innate immune response in experimentally induced bovine intramammary infection with Staphylococcus simulans and S. epidermidis. Vet. Res. 42:49.

Supré, K., S. De Vliegher, O. C. Sampimon, R. N. Zadoks, M. Vaneechoutte, M. Baele, E. De Graef, S. Piepers, and F. Haesebrouck. 2009. Technical note: use of transfer RNA-intergenic spacer PCR combined with capillary electrophoresis to identify coagulase-negative Staphylococcus species originating from bovine milk and teat apices. J. Dairy Sci. 92:3204-3210.

Supré, K. F. Haesebrouck, R. N. Zadoks, M. Vaneechoutte, S. Piepers, and S. De Vliegher. 2011. Some coagulase-negative Staphylococcus species affect udder health more than others. J. Dairy Sci. 94:2329-2340.

Taponen, S., and S. Pyörälä. 2009. Coagulase-negative staphylococci as cause of bovine mastitis-Not so different from Staphylococcus aureus? Vet. Microbiol. 134:29-36. 
Thomsen, A. C., S. C. Mogensen, and F. Love Jepsen. 1985. Experimental mastitis in mice induced by coagulase-negative staphylococci isolated from cases of mastitis in nursing women. Acta Obstet. Gynecol. Scand. 64:163-166.

Thorberg, B. M., M. L. Danielsson-Tham, U. Emanuelson, and K. Persson Waller. 2009. Bovine subclinical mastitis caused by different types of coagulase-negative staphylococci. J. Dairy Sci. 92:4962-4970.
Vanderhaeghen, W., S. Piepers, F. Leroy, E. Van Coillie, F. Haesebrouck, and S. De Vliegher. 2014. Invited review: Effect, persistence, and virulence of coagulase-negative Staphylococcus species associated with ruminant udder health. J. Dairy Sci. 97:5275-5293.

Zadoks, R. N., and J. L. Watts. 2009. Species identification of coagulase-negative staphylococci: Genotyping is superior to phenotyping. Vet. Microbiol. 134:20-28. 